\title{
Application of Biodegradable Polyhydroxyalkanoates as Surgical Films for Ventral Hernia Repair in Mice
}

\author{
Yun Chen, ${ }^{1,2}$ Ya-Hui Tsai, ${ }^{1}$ I-Ning Chou, ${ }^{2}$ Sheng-Hong Tseng, ${ }^{3}$ and Ho-Shing Wu ${ }^{2}$ \\ ${ }^{1}$ Department of Surgery, Far Eastern Memorial Hospital, Pan-Chiao, New Taipei 220, Taiwan \\ ${ }^{2}$ Department of Chemical Engineering and Materials Science, Yuan Ze University, 135 Yuan Tung Road, Chung-Li, \\ Taoyuan 32003, Taiwan \\ ${ }^{3}$ Department of Surgery, National Taiwan University Hospital, National Taiwan University College of Medicine, Taipei 100, Taiwan \\ Correspondence should be addressed to Sheng-Hong Tseng; tsh5110@ntu.edu.tw and Ho-Shing Wu; cehswu@saturn.yzu.edu.tw
}

Received 19 August 2014; Accepted 10 October 2014; Published 5 November 2014

Academic Editor: Robert A. Shanks

Copyright (C) 2014 Yun Chen et al. This is an open access article distributed under the Creative Commons Attribution License, which permits unrestricted use, distribution, and reproduction in any medium, provided the original work is properly cited.

The cytotoxicity and biosafety of poly-(3-hydroxybutyrate) (P3HB) and poly-(3-hydroxybutyrate-co-3-hydroxyvalerate) (P3HBV) films were investigated in vitro using $3 \mathrm{~T} 3$ fibroblast cells and in vivo through subcutaneous implantation of the film in mice. The in vitro test revealed that endotoxin-free $\mathrm{P} 3 \mathrm{HB}$ and $\mathrm{P} 3 \mathrm{HBV}$ films allowed cell attachment and growth. Film-soaked conditional media showed no significant inhibitory or cytotoxic effects on cell proliferation. The in vivo absorption test showed that both the $\mathrm{P} 3 \mathrm{HB}$ and $\mathrm{P} 3 \mathrm{HBV}$ films slowly degraded and that $\mathrm{P} 3 \mathrm{HB}$ had a slower degradation rate than that of $\mathrm{P} 3 \mathrm{HBV}$. Applying a $\mathrm{P} 3 \mathrm{HB}$ film in hernia repair demonstrated a favorable outcome: the film was able to correct the abdominal ventral hernia by inducing connective tissue and fat ingrowth and exhibited an extremely slow rate of degradation. Furthermore, the P3HB film demonstrated the advantage of lower intestinal adhesion to the ventral hernia site compared with the P3HBV and PP commercial films.

\section{Introduction}

Various types of synthetic and biologic film have been developed as meshes for hernia repair $[1,2]$. The key characteristics of an ideal mesh include favorable repair ability and excellent biocompatibility $[1,3]$. Currently, the most widely used materials are polypropylene- (PP-) based meshes of various weights, filament sizes, pore sizes, and weaving structures [46]. Such PP meshes offer the advantage of high burst strength; they are thus highly rigid, and mesh migration and shrinkage seldom occur during repair. Although hernia recurrence is an uncommon complication when PP meshes are used, they tend to induce a chronic inflammatory response to fibrous and tissue ingrowth into the mesh architecture. This provides an opportunity for the adhesion of enteric loops onto the mesh implant, resulting in progressive hardness, abdominal pain, or severe consequences depending on the extent of adhesion [1, 3, 5, 7]. Certain biologic meshes that have been introduced into clinical use in hernia repair are produced using human- or animal-originated tissuegraft $[3,8]$ and are manufactured from collagen-rich tissues such as ligament and dermal grafts that have had their cellular contents completely removed. The resulting cellular collagen matrix provides an alternative device for hernia repair. Compared with synthetic meshes, biologic meshes are softer and the matrix scaffold can gradually be replaced with the patient's own tissue $[8,9]$. This solves the foreign body sensation and reaction problems that arise from using PP meshes. Nevertheless, the burst strength of biologic meshes is relatively lower and they are more fragile, especially when undergoing a sudden increase in abdominal pressure. This lack of integrity and the problem of recurrence have been reported as clinical complications in the use of these biological materials $[3,8]$. An ideal mesh that meets all of the requirements for permanent hernia repair, namely, high biocompatibility, low levels of foreign body sensation, and long-term biomechanical support, remains to be discovered.

Polyhydroxyalkanoates (PHAs) are emerging materials for producing medical devices [10-13]. PHAs are natural products of microorganisms and serve as carbon and energy storage materials under conditions of limited nitrogen and phosphorous sources. Most PHAs exhibit the structures of 
aliphatic polyesters in terms of carbon, oxygen, and hydrogen. With various lengths of carbon backbone and a broad range of function groups, PHA polymers comprise more than 150 constituents that feature diverse characteristics [14]. Among the various PHA polymers, poly-(3-hydroxybutyrate) (P3HB) and poly-(3-hydroxybutyrate-co-3-hydroxyvalerate) (P3HBV) are the most well-known biomaterials, characterized by their low bioreactivity and slow biodegradation rate $[12,14-16]$. Although most efforts in manufacturing these PHA polymers have been undertaken in the plastics industry, emerging needs for tissue engineering have prompted numerous studies on the medical application of PHA polymers. The medical use of $\mathrm{P} 3 \mathrm{HB}$ and $\mathrm{P} 3 \mathrm{HBV}$ has been extensively investigated in the development of various types of surgical material. A P3HB-composed patch was tested to prevent adhesion between the heart and sternum in heart surgery [17-19]. In both animal and human studies, $\mathrm{P} 3 \mathrm{HB}$ patches have greatly lowered the incidence of postoperative adhesions observed over short and long terms [17, 18]. $\mathrm{P} 3 \mathrm{HB}$ and $\mathrm{P} 3 \mathrm{HBV}$ sheets have been used as bridging and guiding materials for regenerating tissues such as nerve fibers [20] and bone [21, 22]. A $\mathrm{P} 3 \mathrm{HB}$ patch was used as a scaffold material in repairing the atrial septal defect in calves, demonstrating evident regeneration of the atrial septal wall with gradual degradation of the patch by macrophages [23]. Other tested functions of P3HB- and P3HBV-based materials include cardiovascular stents, barrier films for dental treatment, and microparticulate carriers for drug delivery [11-14]. However, no study has investigated $\mathrm{P} 3 \mathrm{HB}$ or $\mathrm{P} 3 \mathrm{HBV}$ as hernia repair films.

In this study, we assessed the application of $\mathrm{P} 3 \mathrm{HB}$ and $\mathrm{P} 3 \mathrm{HBV}$ films in ventral hernia repair. The biocompatibility of $\mathrm{P} 3 \mathrm{HB}$ and $\mathrm{P} 3 \mathrm{HBV}$ films was tested in vitro, and their bioabsorption and hernia repair abilities were evaluated in vivo over duration of 9 mo.

\section{Materials and Methods}

2.1. Polymer Films. P3HB (98\%) was produced using recombinant Escherichia coli XL1 blue in our laboratory [24]. P3HBV (5 wt\% 3-hydroxyvalerate) was purchased from Sigma-Aldrich (St. Louis, MO, USA). The film production procedure was described in our previous study [24]. In brief, the polymer films were prepared using a chloroform casting method. The polymer solution $(1.63 \mathrm{wt} \%)$ was poured into a $\Phi 10 \mathrm{~cm}$ glass petri dish and dried in a fume hood to obtain polymer-thin films. The resulting films were dried at ambient temperature in the hood for $3 \mathrm{~d}$ to remove residual chloroform. The physics-chemical properties of $\mathrm{P} 3 \mathrm{HB}$ and $\mathrm{P} 3 \mathrm{HBV}$ polymer films are listed in Table 1 . To ensure that the films were endotoxin-free, they were further treated with $35 \%$ hydrogen peroxide $\left(\mathrm{H}_{2} \mathrm{O}_{2}\right)$ at $80^{\circ} \mathrm{C}$ for $1 \mathrm{~h} \mathrm{[25].}$ Endotoxin concentration was determined using a ToxinSensor Chromogenic LAL Endotoxin Assay Kit (GenScript, Piscataway, NJ, USA). The films were washed with sterilized water and dried in a laminar flow cabinet for experimental use. The commercially available PP film (BARD Soft Mesh) was purchased from Davel Inc. (Warwick, RI, USA) and had a pore size of $1-1.5 \mathrm{~mm}$.
TABLE 1: Physics-chemical properties of $\mathrm{P} 3 \mathrm{HB}$ and $\mathrm{P} 3 \mathrm{HBV}$ polymers and films [24].

\begin{tabular}{lcc}
\hline Item & P3HB & P3HBV \\
\hline $\mathrm{Mw}(\mathrm{g} / \mathrm{mol})$ & $1 \times 10^{6}$ & $6.2 \times 10^{5}$ \\
$\mathrm{PDI}$ & 1.85 & 3.18 \\
Film thickness $(\mu \mathrm{m})$ & $32.3 \pm 1.9$ & $32.0 \pm 1.9$ \\
Powder crystallinity $^{\mathrm{a}}(\%)$ & 55.4 & 49.6 \\
Film crystallinity $^{\mathrm{a}}(\%)$ & 42.3 & 36.4 \\
Film average roughness $^{\mathrm{b}}(\mathrm{nm})$ & 165 & 486 \\
Onset temperature of thermal $_{\text {degradation }\left({ }^{\circ} \mathrm{C}\right)^{\mathrm{c}}}$ & 240 & 210 \\
${\text { Thermal degradation at } 100^{\circ} \mathrm{C}\left(\mathrm{s}^{-1}\right)}$ & $6 \times 10^{-10}$ & $2 \times 10^{-8}$ \\
\hline
\end{tabular}

PDI: polydispersity index $=\mathrm{Mw} / \mathrm{Mn}$; Mw: weight average molecular weight; Mn: number average molecular weight.

${ }^{\mathrm{a}}$ Determined by an X-ray diffractometer. ${ }^{\mathrm{b}}$ Atomic force microscope. ${ }^{\mathrm{c}}$ Thermogravimetric analysis.

2.1.1. Direct Contact Cytotoxicity Test. The films were placed at the bottom of the well in a 6-well plate; subsequently, $4 \times 10^{5}$ mouse fibroblast 3T3 cells were seeded into the well with a culture medium. The plate was then incubated in a humidified $37^{\circ} \mathrm{C} \mathrm{CO}_{2}$ incubator. Forty-eight hours later, the culture medium was discarded and the films were washed twice with phosphate-buffered saline (PBS) and fixed with a $1 \%$ formalin solution. The growth of $3 \mathrm{~T} 3$ cells on the films was visualized using crystal violet staining and quantified using microscopic images. The final result was averaged from 3 independent experiments.

2.1.2. Indirect Contact Cytotoxicity Test. The films were soaked in the culture medium and gently shaken in an orbital shaker at $37^{\circ} \mathrm{C}$. Simultaneously, the cells were seeded in the 6 -well plate at a cell density of $4 \times 10^{5} /$ well with the culture medium. Twenty-four hours later, the conditioned medium was harvested and centrifuged at $200 \times \mathrm{g}$ for $3 \mathrm{~min}$ and the supernatant was preserved. The culture medium of the 3T3 cells was aspirated, and the cells were washed with PBS buffer twice. Subsequently, the conditioned medium was added into the indicated wells. The cells were incubated in a humidified $37^{\circ} \mathrm{C} \mathrm{CO}_{2}$ incubator for another $48 \mathrm{~h}$. To observe cell growth, cells in each well were fixed with a $1 \%$ formalin solution followed by crystal violet staining. Cell density was quantified using microscopic images. The final result was averaged from 3 independent experiments.

2.2. Animals. The animal experiments in this study were approved by the Committee on Laboratory Animal Research of the Far Eastern Memorial Hospital, Taiwan, and conducted according to the guidelines of the Laboratory Animal Center of the Far Eastern Memorial Hospital. Five-week-old male $\mathrm{balb} / \mathrm{c}$ mice weighing 15-20 gm were used for the experiments. The mice were provided food and water ad libitum on a 12:12 h day-night cycle (lights on from 0600 to 1800) with room temperature maintained at around $20^{\circ} \mathrm{C}$. 
2.3. Bioabsorption Test. Five-week-old male balb/c mice were purchased from the National Laboratory Animal Center, Taipei, Taiwan. The mice were weighed and anesthetized with Ketamine/Xylazine $(100 \mathrm{mg} / \mathrm{Kg}$ and $10 \mathrm{mg} / \mathrm{Kg}$, resp.). The polymer films were cut into $1 \mathrm{~cm} \times 1 \mathrm{~cm}$ pieces, approximately $2.5 \mathrm{mg}$ each, and were implanted into the subcutaneous region of the abdominal wall. At various time points $(0.5$, 1,3 , and $9 \mathrm{mo}$ ), the implanted films with the adjacent skin and muscular tissue were excised and fixed in $10 \%$ formalin for $24 \mathrm{~h}$. The fixed tissue was then embedded in paraffin and sliced into $5 \mu \mathrm{m}$ thick sections. After hematoxylin and eosin (H\&E) staining, the sections were used for histologically evaluating the tissue response to various films. The remaining film thickness was measured using Image J software (developed by the United States National Institutes of Health). At each time point, 6 mice were used in each group.

2.4. Hernia Repair Ability Test. Five-week-old male balb/c mice were purchased from the National Laboratory Animal Center, Taipei, Taiwan. The mice were weighed and anesthetized with Ketamine/Xylazine $(100 \mathrm{mg} / \mathrm{Kg}$ and $10 \mathrm{mg} / \mathrm{Kg}$, resp.). The polymer films were cut into $1 \mathrm{~cm} \times 1 \mathrm{~cm}$ pieces, approximately $2.5 \mathrm{mg}$. Ventral hernias were introduced by creating a $0.5 \mathrm{~cm} \times 0.5 \mathrm{~cm}$ puncture on the muscle layer of the ventral abdominal wall. The film was then used to cover the puncture, and the 4 corners of the film were sutured to the muscle tissue around the hernia region. At various time points $(0.5,1,3$, and $9 \mathrm{mo})$, the mice were laparotomized through the midline, and the adhesion with adjacent organs was observed. The repair of the abdominal hernia was photographed, and the implanted films with the adjacent skin and abdominal muscle layer were excised and fixed in $10 \%$ formalin for $24 \mathrm{~h}$. The fixed tissue was then embedded in paraffin and sliced into $5 \mu \mathrm{m}$ thick sections, which were stained with $\mathrm{H} \& \mathrm{E}$ to evaluate histologically the residual film areas and nearby tissue response. At each time point, 6 mice were used in each group.

2.5. Immunohistochemistry for Macrophages. The tissue sections were deparaffinized and rehydrated, followed by autoclaving in a pH 6.0 citrate buffer $\left(121^{\circ} \mathrm{C}, 15 \mathrm{~min}\right)$ for antigen retrieval. Endogenous peroxidase activity was blocked using the DAKO peroxidase-blocking reagent (DAKO, Denmark). The primary anti-mouse of anti-CD68 monoclonal antibody (ab31630, Abcam, Cambridge, UK) was used at a dilution of 1:50 and incubated with the sections at $4^{\circ} \mathrm{C}$ overnight. A rabbit anti-mouse secondary antibody (DAKO) was then added, and the slides were incubated at room temperature for $1 \mathrm{~h}$. The color-developing agent $3,3^{\prime}$-diaminobenzidine (DAB) (Abcam) was added and incubated with the sections for $10 \mathrm{~min}$. The sections were then counterstained with hematoxylin to promote visualization of the tissue.

2.6. Statistical Analysis. Student's $t$-test was used to evaluate the differences among various groups, and the statistical significance was accepted only when $P<0.05$.

\section{Results}

The physical properties and thermal behavior of $\mathrm{P} 3 \mathrm{HB}$ and P3HBV films used in this study were in Table 1, reported in our previous work [24].

3.1. Preparation of Endotoxin-Free $P 3 H B$ and $P 3 H B V$ Films. Bacterial endotoxins, which are found in the outer films of gram-negative bacteria, such as E. coli, are members of a class of phospholipids called lipopolysaccharides. Because P3HB is produced using E. coli, the endotoxin must be removed before the films can be used in medical applications. The endotoxin concentration in medical devices approved by the FDA is $0.005 \mathrm{EU} / \mathrm{g}$ [26]. The original $\mathrm{P} 3 \mathrm{HB}$ powder can contain an endotoxin concentration as high as $21100 \mathrm{EU} / \mathrm{g}$. Once a chloroform casting procedure is used to produce a membranous form, the endotoxin concentration within the $\mathrm{P} 3 \mathrm{HB}$ film can be reduced to $1790 \mathrm{EU} / \mathrm{g}$. To achieve FDA-approved standards, we further eliminated traces of endotoxin in the films by using a traditional $\mathrm{H}_{2} \mathrm{O}_{2}$-soaking method [25], successfully reducing endotoxin levels to less than $0.001 \mathrm{EU} / \mathrm{g}$. Similarly, the endotoxin within the P3HBV film $(460 \mathrm{EU} / \mathrm{g})$ was removed to a level under the detection threshold (less than $0.005 \mathrm{EU} / \mathrm{g}$ ).

3.2. In Vitro Cytotoxicity Assays for $\mathrm{P} 3 \mathrm{HB}$ and $\mathrm{P} 3 \mathrm{HBV}$ Films. To investigate the biocompatibility of the $\mathrm{P} 3 \mathrm{HB}$ film, we performed the in vitro cytotoxicity assays specified in the ISO10993-5 standards, including direct and indirect contact tests [27]. Mouse fibroblast cell line 3T3 cells were used in both tests. The $\mathrm{P} 3 \mathrm{HB}$ and $\mathrm{P} 3 \mathrm{HBV}$ films before and after endotoxin removal were tested for comparison.

For the direct contact test, the films were placed in the bottom of the well, and 3T3 cells were directly seeded onto the films with the culture medium. Forty-eight h later, the cells on the films and in the control well (no film) were fixed and stained with crystal violet. Cell growth on each film was photographed (Figure 1(a)), and the relative cell density was calculated by dividing the number of nuclei on each film by that in the control well. Few cells were able to grow on the endotoxin-containing $\mathrm{P} 3 \mathrm{HB}$ and $\mathrm{P} 3 \mathrm{HBV}$ films; the relative cell densities on these films were $0.72 \% \pm 0.35 \%$ and $8.86 \% \pm 3.06 \%$, respectively (Figure $1(\mathrm{~b})$ ). By contrast, the growth of $3 \mathrm{~T} 3$ cells was much more abundant on the endotoxin-free $\mathrm{P} 3 \mathrm{HB}$ and $\mathrm{P} 3 \mathrm{HBV}$ films; the relative cell densities on endotoxin-free $\mathrm{P} 3 \mathrm{HB}$ and $\mathrm{P} 3 \mathrm{HBV}$ films were $37.84 \% \pm 2.99 \%$ and $60.60 \% \pm 7.76 \%$, respectively, and both of which were significantly higher than those on endotoxincontaining $\mathrm{P} 3 \mathrm{HB}$ and $\mathrm{P} 3 \mathrm{HBV}$ films $(P=0.00003$ in $\mathrm{P} 3 \mathrm{HB}$ group and 0.0004 in $\mathrm{P} 3 \mathrm{HBV}$ group) (Figure $1(\mathrm{~b})$ ). This result demonstrated that the $3 \mathrm{~T} 3$ cells were able to attach and grow on both the $\mathrm{P} 3 \mathrm{HB}$ and $\mathrm{P} 3 \mathrm{HBV}$ films that underwent endotoxin removal.

For the indirect contact test, 3T3 cells were incubated with the conditioned media, which was previously soaked with the indicated films for $48 \mathrm{~h}$. After another $48 \mathrm{~h}$ of incubation, cell growth in each well was photographed (Figure 2(a)), and the relative cell densities were calculated by dividing the 
No membrane control

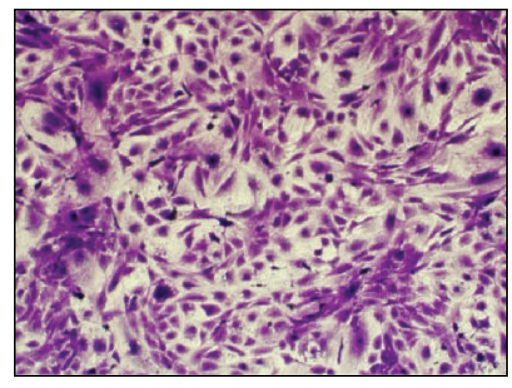

$\mathrm{P} 3 \mathrm{HB}$

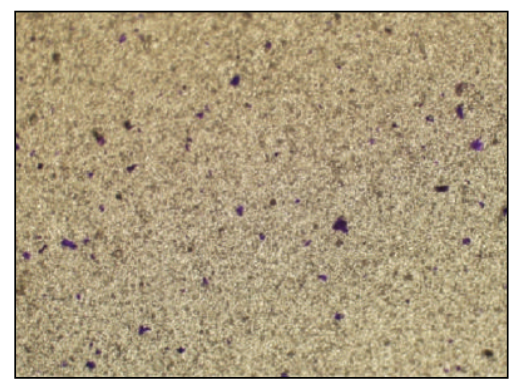

$\mathrm{P} 3 \mathrm{HBV}$

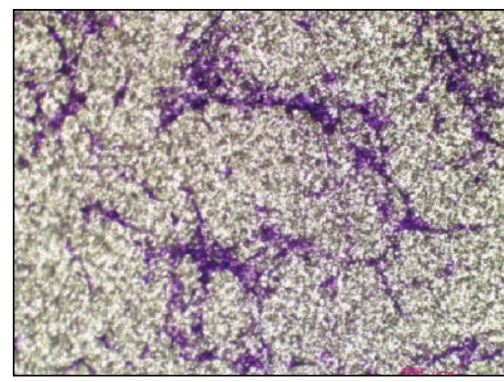

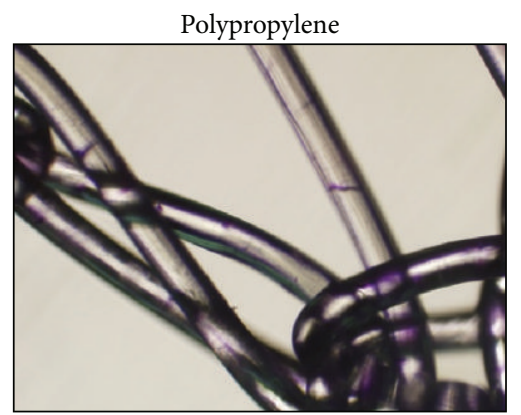

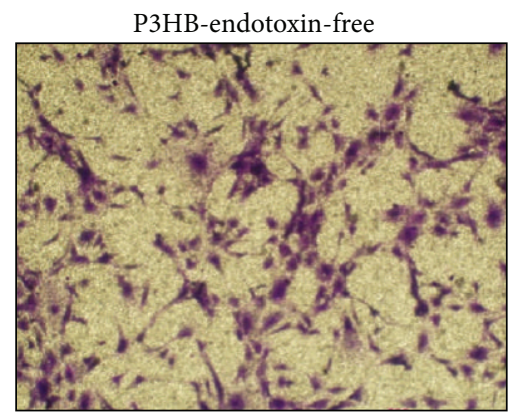

(a)

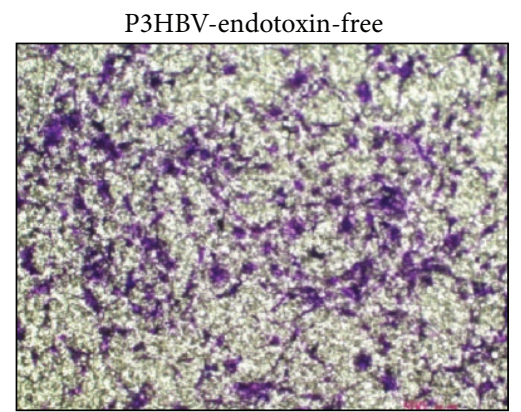

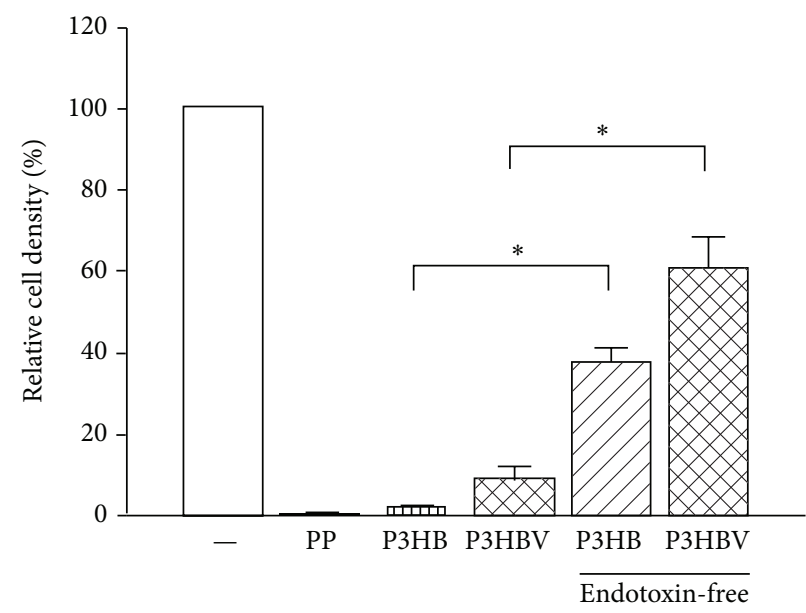

Membrane type

(b)

Figure 1: Direct contact assay using P3HB, P3HBV, and polypropylene materials with mouse 3T3 cells. (a) The film was placed at the bottom of the indicated well followed by seeding $3 \mathrm{~T} 3$ cells into the well with culture medium. Forty-eight hours later, the culture medium was discarded and the cells growing in the empty well (no film control) or on different films were fixed with $1 \%$ formalin solution. The cells were stained with $1 \%(\mathrm{w} / \mathrm{v}$ ) crystal violet solution. (b) Six images in different fields were photographed from each sample, and the nuclei were counted using Image J software. The cell number in the control well was set at 100\%. The bars represent the means of three independent experiments, and the error bars represent the standard deviation. * Statistically significant difference between endotoxin-containing and endotoxin-free films.

number of nuclei in each well by that in the control well. Either no cells or infrequently viable cells were observed growing in the medium on the endotoxin-containing $\mathrm{P} 3 \mathrm{HB}$ and $\mathrm{P} 3 \mathrm{HBV}$ films $(0 \%$ and $29 \% \pm 9.68 \%$ of relative cell density, resp.) (Figure $2(\mathrm{~b})$ ). By contrast, comparable growth rates were observed in the conditioned medium on the endotoxinremoved $\mathrm{P} 3 \mathrm{HB}$ and $\mathrm{P} 3 \mathrm{HBV}$ films $(92.27 \% \pm 8.38 \%$ and $96.78 \% \pm 8.16 \%$ of relative cell density, resp., and both of which were significantly higher than those on endotoxincontaining $\mathrm{P} 3 \mathrm{HB}$ and $\mathrm{P} 3 \mathrm{HBV}$ films $(P=0.00004$ in $\mathrm{P} 3 \mathrm{HB}$ group and 0.0007 in $\mathrm{P} 3 \mathrm{HBV}$ group)) (Figure $2(\mathrm{~b})$ ). This implied that neither the endotoxin-free $\mathrm{P} 3 \mathrm{HB}$ nor the $\mathrm{P} 3 \mathrm{HBV}$ film can release toxic factors that are significantly harmful to 3T3 cells.

Collectively, these in vitro contact assays demonstrated that, after endotoxin removal, the $\mathrm{P} 3 \mathrm{HB}$ and $\mathrm{P} 3 \mathrm{HBV}$ films 

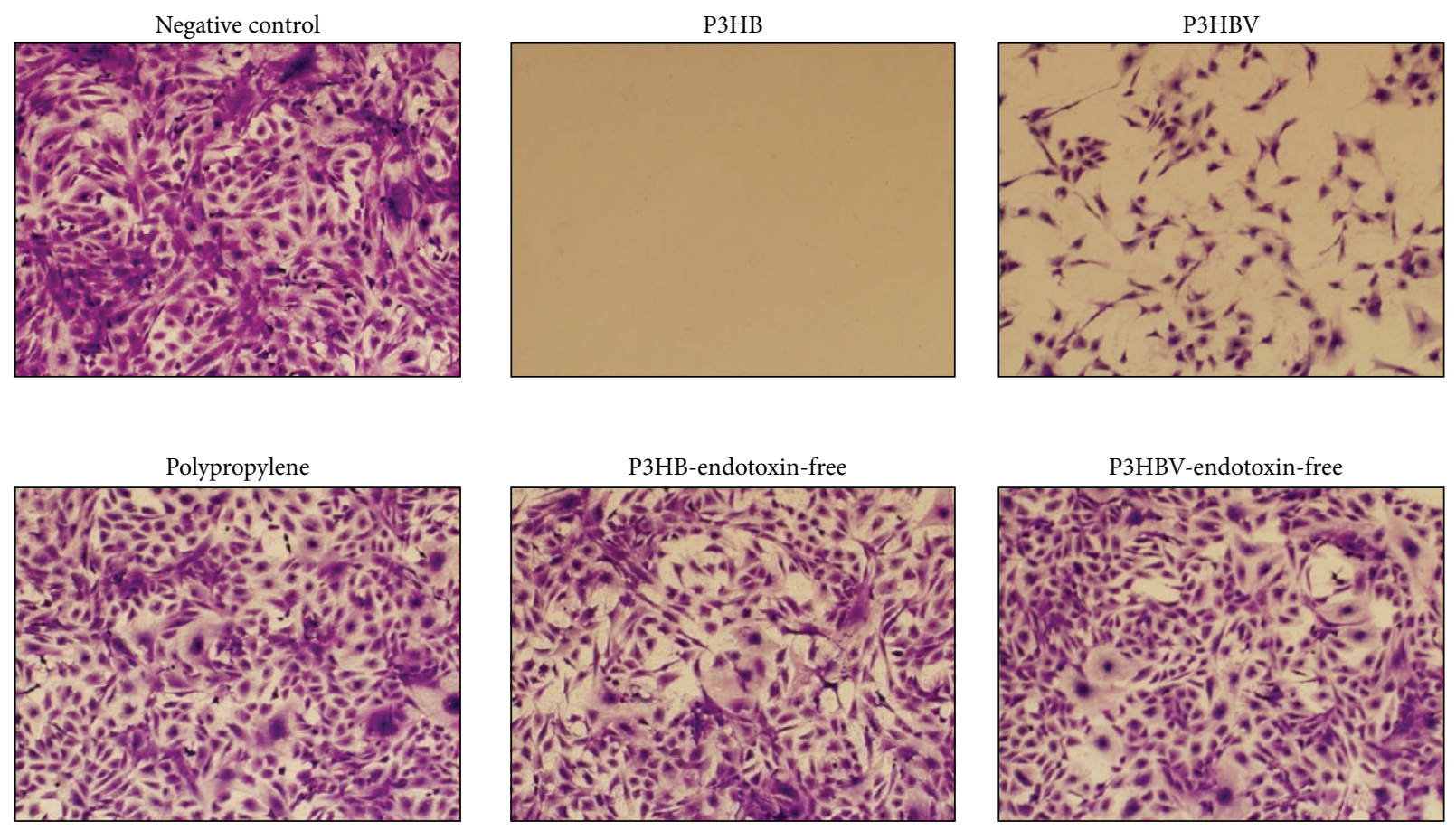

(a)

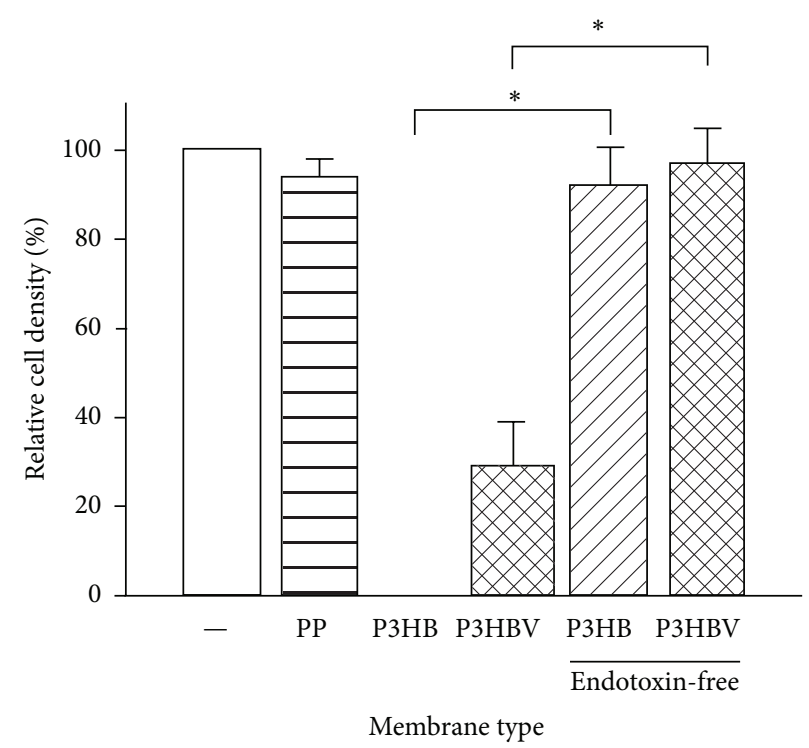

(b)

FIGURE 2: Indirect contact assay using P3HB, P3HBV, and polypropylene materials with mouse 3T3 cells. (a) The film was soaked in a culture medium and gently shaken in an orbital shaker at $37^{\circ} \mathrm{C}$ for $24 \mathrm{~h}$. Twenty-four hours later, the conditioned medium was harvested and used to culture $3 \mathrm{~T} 3$ cells, which were incubated in a humidified $37^{\circ} \mathrm{C} \mathrm{CO}_{2}$ incubator for another $48 \mathrm{~h}$. To observe the cell growth, cells in each well were fixed with $1 \%$ formalin solution and stained with $1 \%$ (w/v) crystal violet solution. (b) Six images in different fields were photographed from each sample, and the nuclei were counted using Image J software. The cell number in the control well was set as $100 \%$. The bars represent the mean values of three independent experiments, and the error bars represent the standard deviation. * Statistically significant difference between endotoxin-containing and endotoxin-free films.

demonstrated low cytotoxicity and high biosafety in facilitating the attachment and growth of fibroblast cells.

3.3. In Vivo Tissue Response and Bioabsorption of $\mathrm{P} 3 \mathrm{HB}$ and $\mathrm{P} 3 \mathrm{HBV}$ Films. To investigate the in vivo cellular interaction of the $\mathrm{P} 3 \mathrm{HB}$ and $\mathrm{P} 3 \mathrm{HBV}$ films, the endotoxin-free $\mathrm{P} 3 \mathrm{HB}$ film, P3HBV film, and PP mesh were implanted into the subcutaneous region of mice. The implant size of the film was $1 \mathrm{~cm} \times 1 \mathrm{~cm}$. At various time points $(0.5,1,3$, and $9 \mathrm{mo})$ after implantation, the implants, adjacent skin, and abdominal 
wall regions were excised and fixed. Using tissue sectioning and $H \& E$ staining, we observed the tissue response to each film and the change in film thickness over time. The $\mathrm{P} 3 \mathrm{HB}$ and $\mathrm{P} 3 \mathrm{HBV}$ implants showed lamina structures with a lining of neutrophils surrounding the film at 0.5 to $1 \mathrm{mo}$. At $3 \mathrm{mo}$, the $\mathrm{P} 3 \mathrm{HB}$ and $\mathrm{P} 3 \mathrm{HBV}$ films were already enveloped by layers of connective tissue, and the tissue layer had thickly accumulated, especially in the P3HBV films. At 6 and 9 mo, neutrophil infiltration was significantly reduced (Figure 3(a)). The PP film filament was observed as the circles and was soon completely covered by impact layers of connective tissue after implantation $(0.5 \mathrm{mo})$. The neutrophil infiltration surrounding the fibers was evident from 0.5 to 6 mo and only slightly lessened at 9 mo (Figure $3(\mathrm{a})$ ). These observations demonstrated that the $\mathrm{P} 3 \mathrm{HB}$ and $\mathrm{P} 3 \mathrm{HBV}$ films elicited a tissue response similar to that of the PP film but to a lesser extent and for a shorter duration.

The P3HBV film began dividing into smaller fragments at early time points (from $1 \mathrm{mo}$ ), and the number of fragments significantly increased afterwards. By contrast, the P3HB film remained structurally intact and broke into a few pieces after 3 mo (Figure 3(a)). To compare the in vivo bioabsorption of the $\mathrm{P} 3 \mathrm{HB}$ and $\mathrm{P} 3 \mathrm{HBV}$ films, the relative percentages of film remnants at various time points were calculated by measuring the film thickness in cross-section. As shown in Figure 3(b), the thicknesses of both films slowly decreased over time. The thicknesses of the $\mathrm{P} 3 \mathrm{HB}$ film were $81.82 \% \pm 5.95 \%$ at 3 mo and $74.14 \% \pm 9.82 \%$ at 9 mo. The relative thicknesses of the $\mathrm{P} 3 \mathrm{HBV}$ film were $72.37 \% \pm 3.94 \%$ at $3 \mathrm{mo}$ and $53.18 \% \pm$ $4.46 \%$ at $9 \mathrm{mo}$ (Figure 3(b)). The absorption of P3HBV film was relatively faster than that of $\mathrm{P} 3 \mathrm{HB}$ film $(P=0.0475)$. According to these results, we concluded that both the $\mathrm{P} 3 \mathrm{HB}$ and $\mathrm{P} 3 \mathrm{HBV}$ films are bioabsorbable and differ in degradation speed and pattern.

3.4. In Vivo Ventral Hernia Repair Ability of the P3HB and $\mathrm{P} 3 \mathrm{HBV}$ Films. To investigate the ventral hernia repair ability of $\mathrm{P} 3 \mathrm{HB}$ and $\mathrm{P} 3 \mathrm{HBV}$ films in vivo, we designed a ventral hernia model in mice by excising a $0.5 \mathrm{~cm} \times$ $0.5 \mathrm{~cm}$ region from the abdominal muscle wall to create a perforated hernia. The endotoxin-free films were used to cover the perforated region and were sutured using the point-fixed method. All of the animals survived the surgical operation and exhibited no signs of infection or rejection. Most crucially, no hernia protrusion was observed during the 9 mo experimental period. At various time points $(0$, $0.5,1,3$, and $9 \mathrm{mo}$ ) after surgery, mice from each group were euthanized, and the status of hernia fixation and tissue adhesion was recorded. Tissues from the repair site, including the film, adjacent skin, and abdominal wall, were harvested for fixation, tissue sectioning, and $\mathrm{H} \& \mathrm{E}$ staining. At $0.5 \mathrm{mo}$, we observed that both the $\mathrm{P} 3 \mathrm{HB}$ and $\mathrm{P} 3 \mathrm{HBV}$ films became transparent and that blood vessels grew in the hernia-covered region (Figure 4(a)). At 1 and $3 \mathrm{mo}$, the films were covered with more tissue ingrowth, and the transparent windows of the films were significantly smaller. At $9 \mathrm{mo}$, the whole films were completely embedded in the growing tissue and vessels (Figure 4(a)).
Postoperative adhesion is one of the critical factors in determining ideal hernia repair materials. Each film was graded according to the probability of adhesion strength from 0 to 3 , where $0=$ "no adhesions," 1 = "adhesions that can be freed easily with gentle tension," 2 = "adhesions that can be freed with blunt dissection," and 3 = "adhesions that require sharp dissection to separate" [28]. As shown in Figure 4(b), the average strength of different films at various time points was compared. The results indicated that the $\mathrm{P} 3 \mathrm{HB}$ film induced less adhesion than P3HBV film or PP mesh at the studied time points $(P<0.05)$, whereas $\mathrm{P} 3 \mathrm{HBV}$ had a similar adhesion grade to that of PP mesh $(P>0.05)$.

3.5. Histological Examination for the Hernia Repair Site. We observed microscopic changes at the hernia repair site based on $\mathrm{H} \& \mathrm{E}$ staining and the extent of chronic inflammatory response by using CD68-positive macrophage staining at 9 mo (Figure 5(a)). Consistent with the bioabsorption test (Figure 3), the $\mathrm{P} 3 \mathrm{HBV}$ film had a higher degradation rate than that of the $\mathrm{P} 3 \mathrm{HB}$ film. The inflammatory response to the P3HB film was limited, and only a thin lining of connective tissue was under the film, with a thick layer of fat cells facing the peritoneal cavity. The inflammation response induced by the P3HBV film was not absent or reduced, as in the bioabsorption test at the same time point indicated. Highly degraded fragments of the P3HBV film were surrounded by lymphocytes and a thick connective tissue layer at the repair site. The number of macrophages was low, and they were located only near the breaking fragments (Figure 5(a)). The PP film also resulted in a heavy inflammatory response and even exhibited a granuloma formed at the repair site (Figure 5(a)).

We compared tissue thicknesses at the repair site for various materials groups. The $\mathrm{P} 3 \mathrm{HB}, \mathrm{P} 3 \mathrm{HBV}$, and $\mathrm{PP}$ groups exhibited thicknesses of $316.85 \pm 119.87 \mu \mathrm{m}, 843.10 \pm$ $173.61 \mu \mathrm{m}$, and $929.13 \pm 163.74 \mu \mathrm{m}$, respectively, at $9 \mathrm{mo}$ (Figure 5(b)). These data showed that hernia repair using the P3HB film caused less tissue thickening compared with using the P3HBV film $(P=0.0001)$ or PP mesh $(P=0.00002)$.

\section{Discussion}

Adhesion-related complications after ventral hernia repair surgery have been a key problem in the use of PP meshes. Biologic meshes do not demonstrate consequential immunological interaction with tissue but have exhibited relatively weaker repair strength compared with synthetic meshes [3, $7,9]$. The search for next-generation materials offering the advantages of PP and synthetic meshes is ongoing. New polymers and mixed-type synthetic materials have been tested and evaluated for their antiadhesive qualities [29-33]. In this research, we demonstrated that PHA-derived materials are a potential choice for hernia repair. PHA materials were tested for their medical use in surgical repair, particularly regarding adhesion prevention [34]. This is the first study to use PHA materials as films for hernia repair. Our results demonstrate that 2 types of PHA film, $\mathrm{P} 3 \mathrm{HB}$ in particular, are qualified for use in hernia repair. 


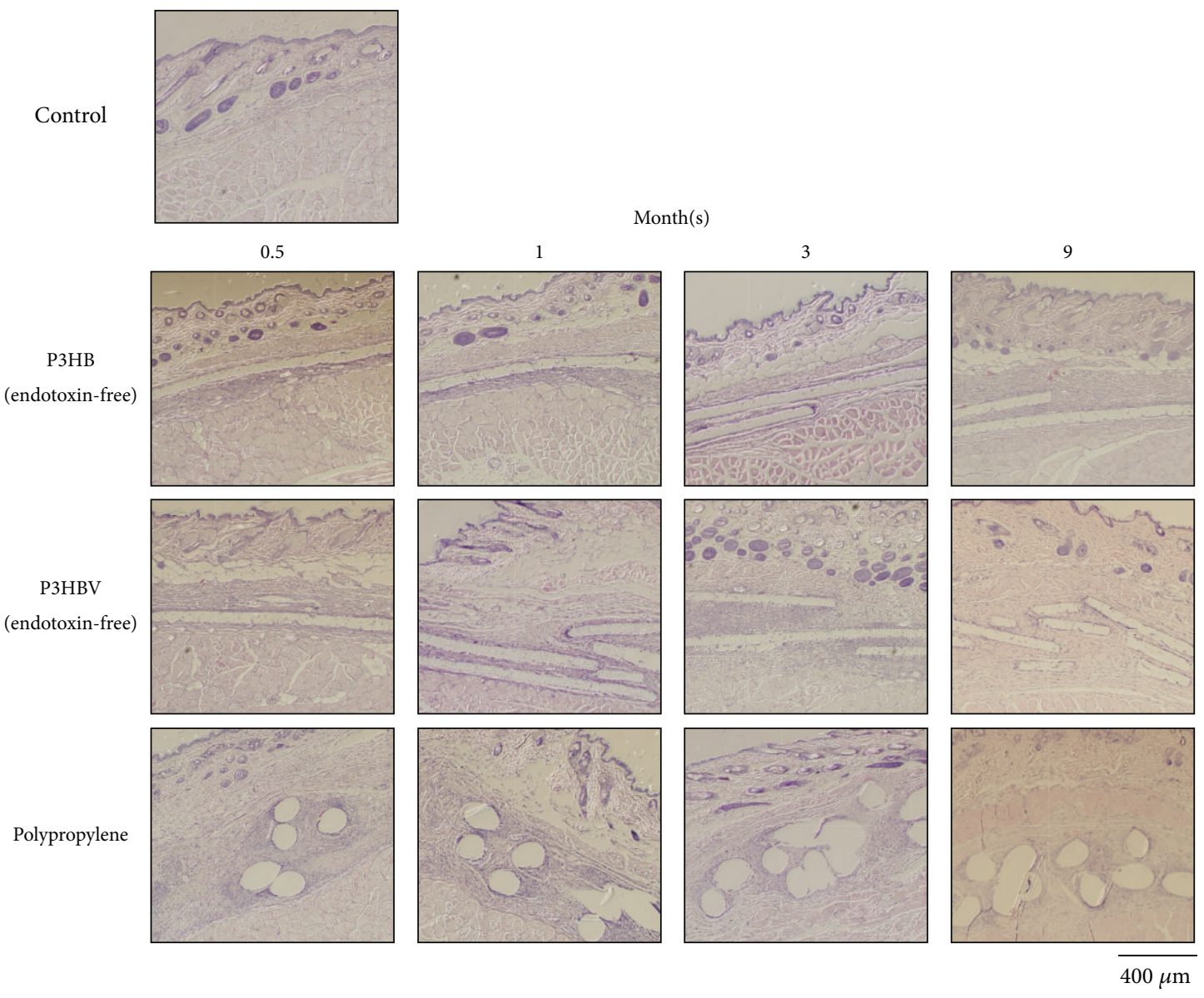

(a)

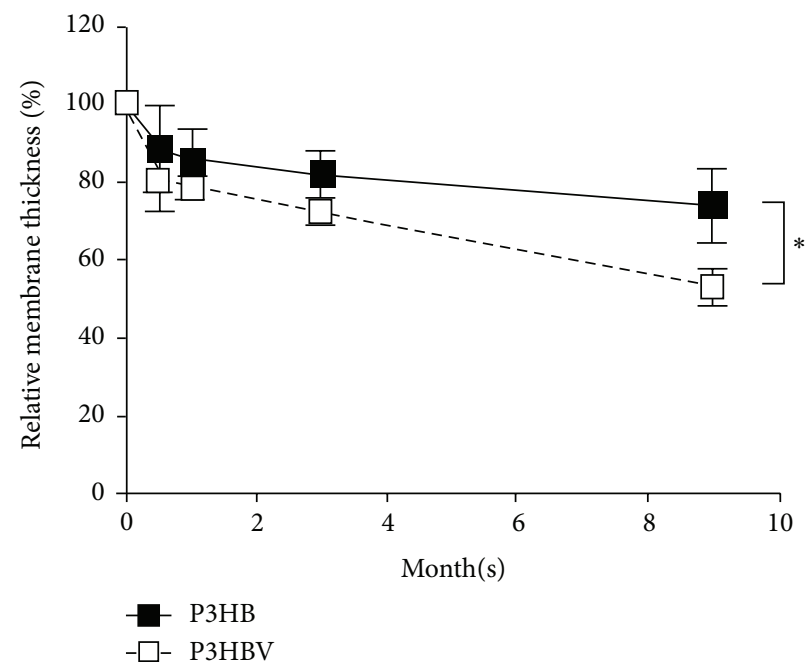

(b)

FIgURE 3: In vivo bioabsorption of endotoxin-free $\mathrm{P} 3 \mathrm{HB}$ and $\mathrm{P} 3 \mathrm{HBV}$ films. The polymer films were cut to $1 \mathrm{~cm} \times 1 \mathrm{~cm}$ pieces and were implanted into the subcutaneous region of the abdominal wall. After different time points $(0.5,1,3$, and 9 mo), the implanted films with the adjacent skin and muscular tissue were excised and subjected to tissue sectioning. (a) Through H\&E staining, the sections were used for histologically evaluating the tissue response to different films. The scale bar represents $400 \mu \mathrm{m}$. (b) The remaining thickness of the indicated endotoxin-free film was measured using Image J software. Three slides from each tissue sample were observed and photographed. The film thickness was calculated using Image J software. The cell number in the control well was set at $100 \%$. The plots represent the mean values of three independent experiments, and the error bars represent the standard deviation. * Statistically significant difference between $\mathrm{P} 3 \mathrm{HB}$ and P3HBV groups. 


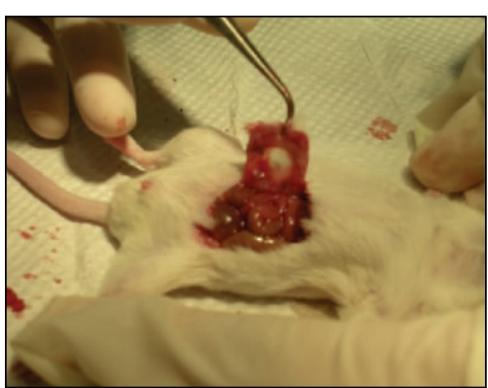

P3HB 0.5 months

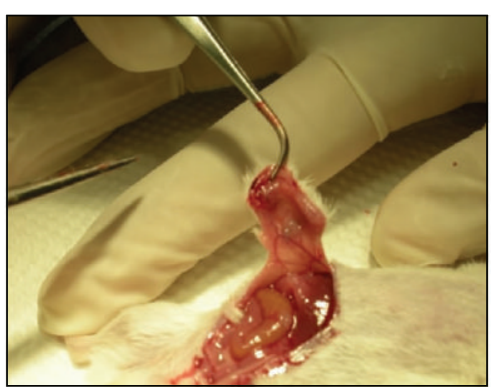

P3HB 1 month

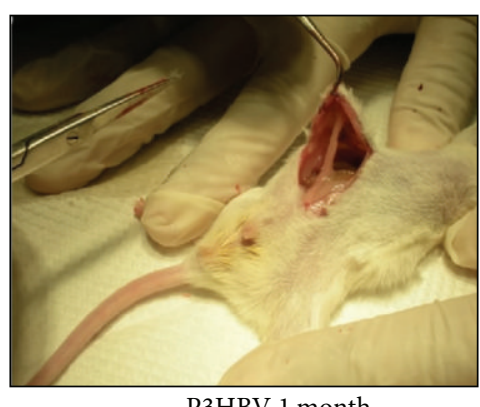

P3HBV 1 month

(a)

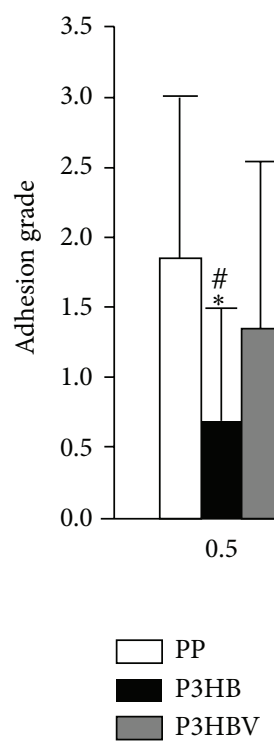

(b)

FIGURE 4: P3HB and P3HBV films at the hernia repair site. (a) Images of P3HB and P3HBV films and surrounding tissue at different time points after hernia repair. (b) The adhesion grade of $\mathrm{P} 3 \mathrm{HB}, \mathrm{P} 3 \mathrm{HBV}$, and polypropylene (PP) films for hernia repair was evaluated in different materials groups. The bars represent the mean values of 6 mice, and the error bars represent the standard deviation. ${ }^{*}$ Statistically significant difference between the PP group and P3HB groups. "Statistically significant difference between the P3HBV and P3HB groups.

The biocompatibility of $\mathrm{P} 3 \mathrm{HB}$ and $\mathrm{P} 3 \mathrm{HBV}$ has been extensively studied both in vitro and in vivo. Korsatko et al. reported no significant impact of $\mathrm{P} 3 \mathrm{HB}$ on the cell growth of mouse fibroblasts [35]. Saito et al. used P3HB film to conduct an inflammatory test on the chorioallantoic film of an egg and reported that the polymer film did not cause significant inflammation [36]. Chaput et al. evaluated the cellular response to $\mathrm{P} 3 \mathrm{HBV}$ by using a direct contact assay and reported that solid polymers had a mild effect on cells [15]. Dang tested the cytotoxic effects of an extract of P3HBV by using a mouse fibroblast cell culture and reported that the extract only slightly suppressed cell activity [37]. For in vivo tests, Doyle et al. demonstrated that P3HB scaffolds did not provoke a chronic inflammatory response after implantation in rabbits after up to $12 \mathrm{mo}$. Chaput et al. observed the tissue response to $\mathrm{P} 3 \mathrm{HBV}$ film in sheep for up to $90 \mathrm{wk}$, revealing an acute inflammatory reaction $1 \mathrm{wk}$ after implantation that was lessened at $11 \mathrm{wk}$. Furthermore, the films were eventually encapsulated with oriented fiber tissue and a large number of fatty cells $[15,38]$. Similarly, Gogolewski et al. (1993) monitored the tissue response to $\mathrm{P} 3 \mathrm{HB}$ and reported that the fibrous capsule around the polymer appeared thickest at $1 \mathrm{mo}$ and became gradually thinner by 6 mo [39]. These studies have revealed that both $\mathrm{P} 3 \mathrm{HB}$ and $\mathrm{P} 3 \mathrm{HBV}$ are biocompatible, nontoxic materials that can be considered potential candidates for use in medical devices.

The degradation of $\mathrm{P} 3 \mathrm{HB}$ was evaluated in vitro in earlier research [14], revealing that P3HB films degraded extremely slowly both in a phosphate buffer and human serum at $37^{\circ} \mathrm{C}$ and that the film sustained weight loss of only $5 \%$ in the first $6 \mathrm{mo}$. In our study, the in vivo biodegradation of the $\mathrm{P} 3 \mathrm{HB}$ film was faster and its thickness decreased by $19 \%$ and $26 \%$ by 3 and 9 mo, respectively (Figure 3(b)). Loss of thickness and structural breakdown occurred earlier in the P3HBV film than in the P3HB film (Figure 3(b)).

The P3HB film exhibited superior performance in affecting low levels of tissue response and had a low adhesion rate compared with P3HBV and PP (Figures 3(a) and 4(b)). At 9 mo after hernia repair, a thin layer of connective tissue with a layer of abundant fat cells was at the repair site. The 


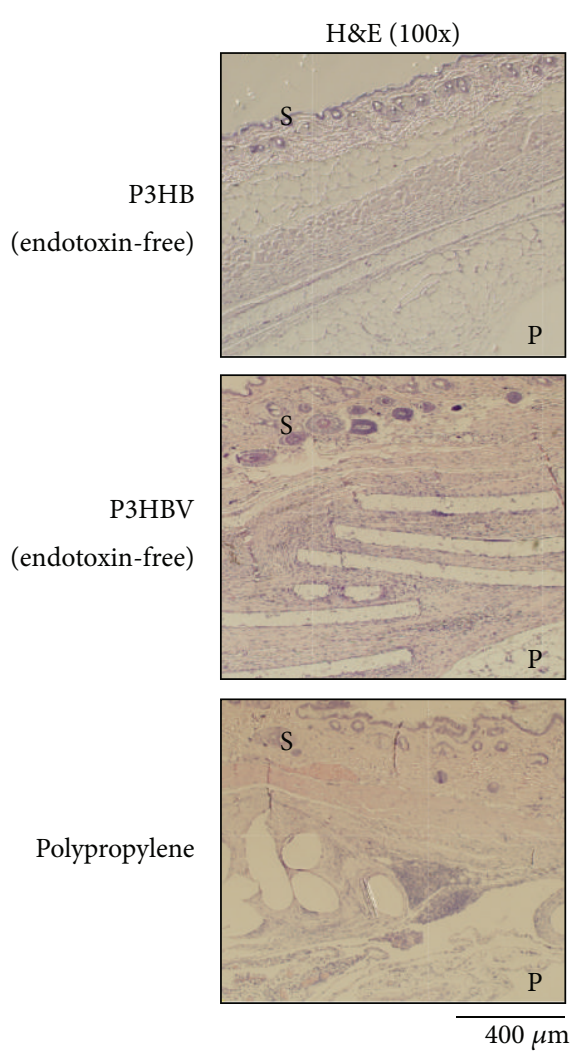

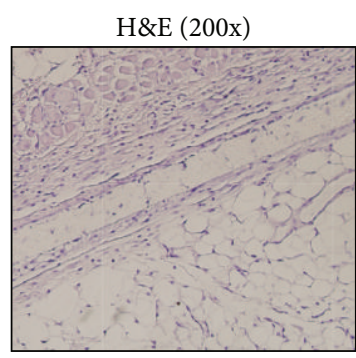
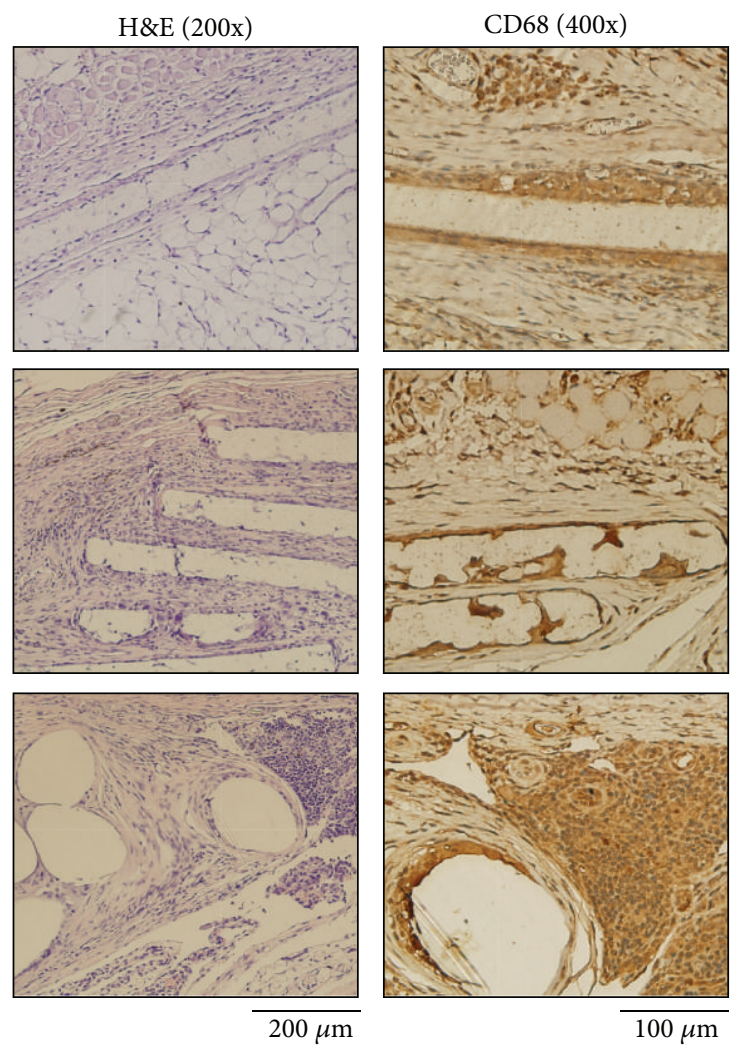

$100 \mu \mathrm{m}$
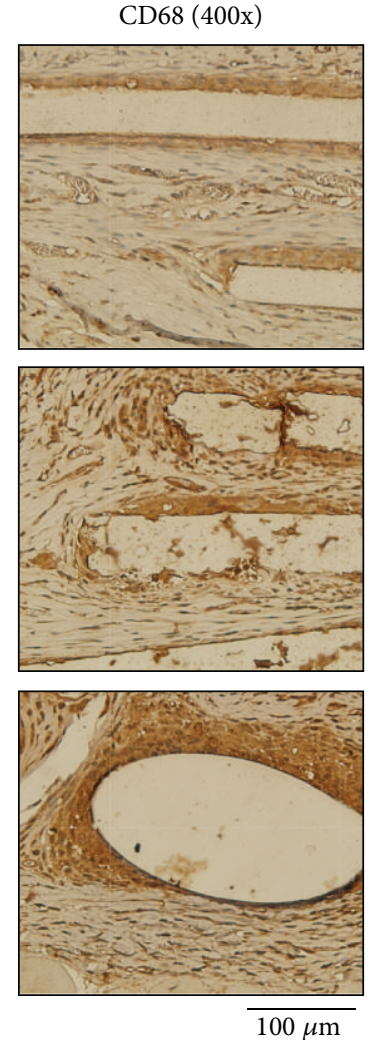

(a)

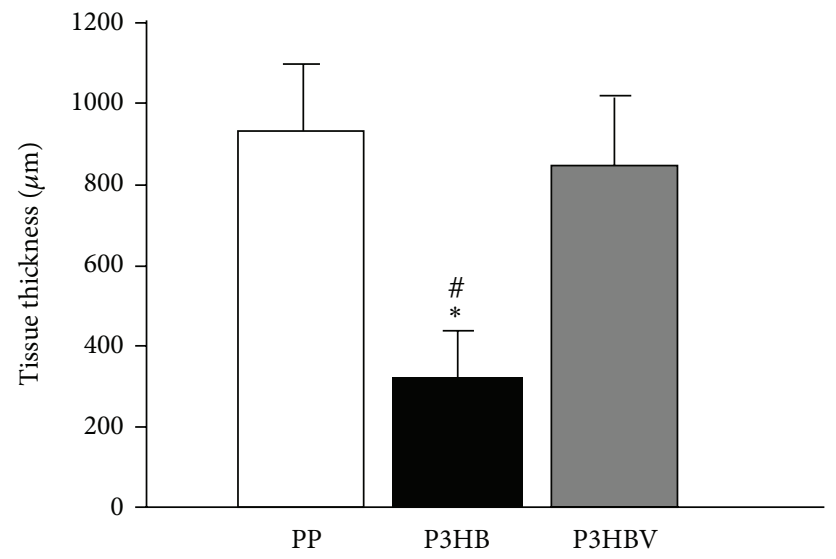

(b)

Figure 5: Tissue reaction to the $\mathrm{P} 3 \mathrm{HB}$ and $\mathrm{P} 3 \mathrm{HBV}$ films at the hernia repair site. (a) Histological images of P3HB, P3HBV, and polypropylene (PP) films and surrounding tissue at different time points after hernia repair. The slides were stained using the H\&E and immunohistochemistry methods for CD68-positive macrophage. $\mathrm{S}=$ skin; $\mathrm{P}=$ peritoneal cavity. The scale bars represent different magnification levels indicated below the bottom row. (b) The thickness of tissue below the film was calculated using Image J software. The bars represent the mean values of 6 mice, and the error bars represent the standard deviation. * Statistically significant difference between the $\mathrm{PP}$ and $\mathrm{P} 3 \mathrm{HB}$ groups. "Statistically significant difference between the P3HBV and P3HB groups.

reason for a high accumulation of fat in the $\mathrm{P} 3 \mathrm{HB}$ film was unclear. However, these fat cells may have been a crucial factor contributing to the extremely low adhesion rate of the $\mathrm{P} 3 \mathrm{HB}$ film (Figures 4 and 5). Compared with the $\mathrm{P} 3 \mathrm{HB}$ film, the $\mathrm{P} 3 \mathrm{HBV}$ film demonstrated relatively higher levels of tissue response, possibly because of its higher degradation rate and greater number of fragments. Consequently, $\mathrm{P} 3 \mathrm{HBV}$ repair induced a compact and thicker layer of connective tissue. The interface between the connective tissue and peritoneal cavity was considerably smooth and exhibited fat cells (Figure 5). The adhesion rate of the $\mathrm{P} 3 \mathrm{HBV}$ film was slightly lower than that of the PP mesh (Figure 4(b)). The 
repair site of the PP mesh was irregularly shaped, and the mesh fibers were blended with immune cells, connective tissue, and some membranous structures in the abdominal cavity (Figure 5(a)). The immune response toward all 3 films lasted longer in the hernia repair experiment than in the bioabsorption experiment. This may have resulted from the hernia wound and the interaction with the peritoneal cavity instead of the abdominal wall. Nevertheless, the most foreign body reaction, especially against the PP mesh, resulted in progressive tissue growth. This could be the main reason for its high level of postoperative complications.

\section{Conclusions}

The results of this study demonstrate that PHA films, particularly $\mathrm{P} 3 \mathrm{HB}$, are potential materials for hernia fixation. Such films can be modified further, by using P3HBV with various percentages of 3-hydroxyvalerate, for example. Alternatively, a dual-layer film in which $\mathrm{P} 3 \mathrm{HB}$ faces the peritoneal cavity can lower the adhesion grade; $\mathrm{P} 3 \mathrm{HBV}$ facing the dermis side can thicken tissue growth at the repair site. In conclusion, PHA-based films are potent and promising materials for future hernia repair.

\section{Conflict of Interests}

The authors declare that there is no conflict of interests regarding the publication of this paper.

\section{Acknowledgments}

The authors thank the National Science Council of Taiwan for financially supporting this research under Grant nos. NSC 101-2632-E-155-001-MY3 and 102-2221-E-155-056.

\section{References}

[1] D. L. Sanders and A. N. Kingsnorth, "Prosthetic mesh materials used in hernia surgery," Expert Review of Medical Devices, vol. 9, no. 2, pp. 159-179, 2012.

[2] V. Schumpelick and U. Klinge, "Prosthetic implants for hernia repair," The British Journal of Surgery, vol. 90, no. 12, pp. 14571458, 2003.

[3] S. Bringman, J. Conze, D. Cuccurullo et al., "Hernia repair: the search for ideal meshes," Hernia, vol. 14, no. 1, pp. 81-87, 2010.

[4] T. S. de Vries Reilingh, D. van Geldere, B. Langenhorst et al., "Repair of large midline incisional hernias with polypropylene mesh: Comparison of three operative techniques," Hernia, vol. 8, no. 1, pp. 56-59, 2004.

[5] A. Huber, G. P. McCabe, A. V. Boruch, C. Medberry, M. Honerlaw, and S. F. Badylak, "Polypropylene-containing synthetic mesh devices in soft tissue repair: a meta-analysis," Journal of Biomedical Materials Research B: Applied Biomaterials, vol. 100, no. 1, pp. 145-154, 2012.

[6] B. Klosterhalfen, K. Junge, and U. Klinge, "The lightweight and large porous mesh concept for hernia repair," Expert Review of Medical Devices, vol. 2, no. 1, pp. 103-117, 2005.

[7] T. N. Robinson, J. H. Clarke, J. Schoen, and M. D. Walsh, "Major mesh-related complications following hernia repair," Surgical
Endoscopy and Other Interventional Techniques, vol. 19, no. 12, pp. 1556-1560, 2005.

[8] P. Brown, "Abdominal wall reconstruction using biological tissue grafts," AORN Journal, vol. 90, no. 4, pp. 513-524, 2009.

[9] U. Klinge and B. Klosterhalfen, "Modified classiffication of surgical meshes for hernia repair based on the analyses of 1,000 explanted meshes," Hernia, vol. 16, no. 3, pp. 251-258, 2012.

[10] S. F. Williams and D. P. Martin, "Applications of PHAs in medicine and pharmacy," Biopolymers, vol. 4, pp. 91-127, 2002.

[11] G.-Q. Chen and Q. Wu, "The application of polyhydroxyalkanoates as tissue engineering materials," Biomaterials, vol. 26, no. 33, pp. 6565-6578, 2005.

[12] G.-Q. Chen, "A microbial polyhydroxyalkanoates (PHA) based bio- and materials industry," Chemical Society Reviews, vol. 38, no. 8, pp. 2434-2446, 2009.

[13] C. J. Brigham and A. J. Sinskey, "Applications of polyhydroxyalkanoates in the medical industry," International Journal of Biotechnology for Wellness Industries, vol. 1, pp. 53-60, 2012.

[14] A. Bonartsev, V. Myshkina, D. Nikolaeva et al., "Biosynthesis, biodegradation, and application of poly (3-hydroxybutyrate) and its copolymers-natural polyesters produced by diazotrophic bacteria," in Communicating Current Research and Educational Topics and Trends in Applied Microbiology, vol. 1, pp. 295-307, 2007.

[15] C. Chaput, L. H. Yahia, A. Selmani, and C.-H. Rivard, MRS Proceedings, Cambridge University Press, 1995.

[16] V. Hasirci, "Biodegradable biomedical polymers. Review of degradation of and in vivo responses to polylactides and polyhydroxyalkanoates," in Biomaterials and Bioengineering Handbook, pp. 141-155, Marcel Dekker, New York, NY, USA, 2000.

[17] T. Malm, S. Bowald, A. Bylock, and C. Busch, "Prevention of postoperative pericardial adhesions by closure of the pericardium with absorbable polymer patches: an experimental study," The Journal of Thoracic and Cardiovascular Surgery, vol. 104, no. 3, pp. 600-607, 1992.

[18] O. Duvernoy, T. Malm, J. Ramstrom, and S. Bowald, "A biodegradable patch used as a pericardial substitute after cardiac surgery: 6- and 24-month evaluation with CT," The Thoracic and Cardiovascular Surgeon, vol. 43, no. 5, pp. 271-274, 1995.

[19] S. F. Bowald and E. G. Johansson, "A novel surgical material," European Patent Application 0349505 A 2. 1990.

[20] A. Hazari, G. Johansson-Rudén, K. Junemo-Bostrom et al., "A new resorbable wrap-around implant as an alternative nerve repair technique," Journal of Hand Surgery, vol. 24, no. 3, pp. 291-295, 1999.

[21] L. Kostopoulos and T. Karring, "Guided bone regeneration in mandibular defects in rats using a bioresorbable polymer," Clinical Oral Implants Research, vol. 5, no. 2, pp. 66-74, 1994.

[22] L. Kostopoulos and T. Karring, "Augmentation of the rat mandible using guided tissue regeneration," Clinical Oral Implants Research, vol. 5, no. 2, pp. 75-82, 1994.

[23] T. Malm, S. Bowald, S. Karacagil, A. Bylock, and C. Busch, "A new biodegradable patch for closure of atrial septal defect: an experimental study," Scandinavian Journal of Thoracic and Cardiovascular Surgery, vol. 26, no. 1, pp. 9-14, 1992.

[24] Y. Chen, I.-N. Chou, Y.-H. Tsai, and H.-S. Wu, “Thermal degradation of poly(3-hydroxybutyrate) and poly(3-hydroxybutyrate-co-3-hydroxyvalerate) in drying treatment," Journal of Applied Polymer Science, vol. 130, no. 5, pp. 3659-3667, 2013. 
[25] S. F. Williams, D. P. Martin, D. M. Horowitz, and O. P. Peoples, "PHA applications: addressing the price performance issue I. Tissue engineering," International Journal of Biological Macromolecules, vol. 25, no. 1-3, pp. 111-121, 1999.

[26] Bacterial endotoxins/pyrogens in the website of U.S. Food and Drug Administration, 2014, http://www.fda.gov/ ICECI/Inspections/InspectionGuides/InspectionTechnicalGuides/ucm072918.htm.

[27] M. N. Helmus, D. F. Gibbons, and D. Cebon, "Biocompatibility: meeting a key functional requirement of next-generation medical devices," Toxicologic Pathology, vol. 36, no. 1, pp. 70-80, 2008.

[28] C. E. Butler, F. A. Navarro, and D. P. Orgill, "Reduction of abdominal adhesions using composite collagen-GAG implants for ventral hernia repair," Journal of Biomedical Materials Research, vol. 58, pp. 75-80, 2001.

[29] M. Chen, P. O. Zamora, P. Som, L. A. Peña, and S. Osaki, "Cell attachment and biocompatibility of polytetrafluoroethylene (PTFE) treated with glow-discharge plasma of mixed ammonia and oxygen," Journal of Biomaterials Science, Polymer Edition, vol. 14, no. 9, pp. 917-935, 2003.

[30] I. Felemovicius, M. E. Bonsack, G. Hagerman, and J. P. Delaney, "Prevention of adhesions to polypropylene mesh," Journal of the American College of Surgeons, vol. 198, no. 4, pp. 543-548, 2004.

[31] R. Leszczynski, E. Stodolak, J. Wieczorek, J. OrlowskaHeitzman, T. Gumula, and S. Blazewicz, "In vivo biocompatibility assessment of (PTFE-PVDF-PP) terpolymer-based membrane with potential application for glaucoma treatment," Journal of Materials Science: Materials in Medicine, vol. 21, no. 10, pp. 2843-2851, 2010.

[32] C. Weis, E. K. Odermatt, J. Kressler, Z. Funke, T. Wehner, and D. Freytag, "Poly(vinyl alcohol) membranes for adhesion prevention," Journal of Biomedical Materials Research. Part B, Applied Biomaterials, vol. 70, no. 2, pp. 191-202, 2004.

[33] J. Conze, K. Junge, C. Weiß et al., "New polymer for intraabdominal meshes-PVDF copolymer," Journal of Biomedical Materials Research-Part B Applied Biomaterials, vol. 87, no. 2, pp. 321-328, 2008.

[34] D. Behrend, C. Nischan, C. Kunze, M. Sa, and K. Schmitz, "Resorbable scaffolds for tissue engineering," Medical \& Biological Engineering \& Computing, vol. 37, pp. 1510-1511, 1999.

[35] W. Korsatko, B. Wabnegg, and H. M. Tillian, "Poly-D-(-)-3hydroxybutyric acid: a biodegradable carrier for long term medication dosage. II. Comm.: the biodegradation in animal organism and in-vitro-in-vivo correlation of the liberation of pharmaceuticals from parenteral matrix retard tablets," Pharmazeutische Industrie, vol. 45, no. 10, pp. 1004-1007, 1983.

[36] T. Saito, K. Tomita, K. Juni, and K. Ooba, "In vivo and in vitro degradation of poly(3-hydroxybutyrate) in rat," Biomaterials, vol. 12 , no. 3, pp. 309-312, 1991.

[37] M.-H. Dang, "Toxicity screening of biodegradable polymers. I. Selection and evaluation of cell culture test methods," Journal of Environmental Polymer Degradation, vol. 4, no. 3, pp. 197-203, 1996.

[38] C. Doyle, E. T. Tanner, and W. Bonfield, "In vitro and in vivo evaluation of polyhydroxybutyrate and of polyhydroxybutyrate reinforced with hydroxyapatite," Biomaterials, vol. 12, no. 9, pp. 841-847, 1991.

[39] S. Gogolewski, M. Jovanovic, S. M. Perren, J. G. Dillon, and M. K. Hughes, "Tissue response and in vivo degradation of selected polyhydroxyacids: polylactides (PLA), poly(3hydroxybutyrate) (PHB), and poly(3- hydroxybutyrate-co-3hydroxyvalerate) (PHB/VA)," Journal of Biomedical Materials Research, vol. 27, no. 9, pp. 1135-1148, 1993. 

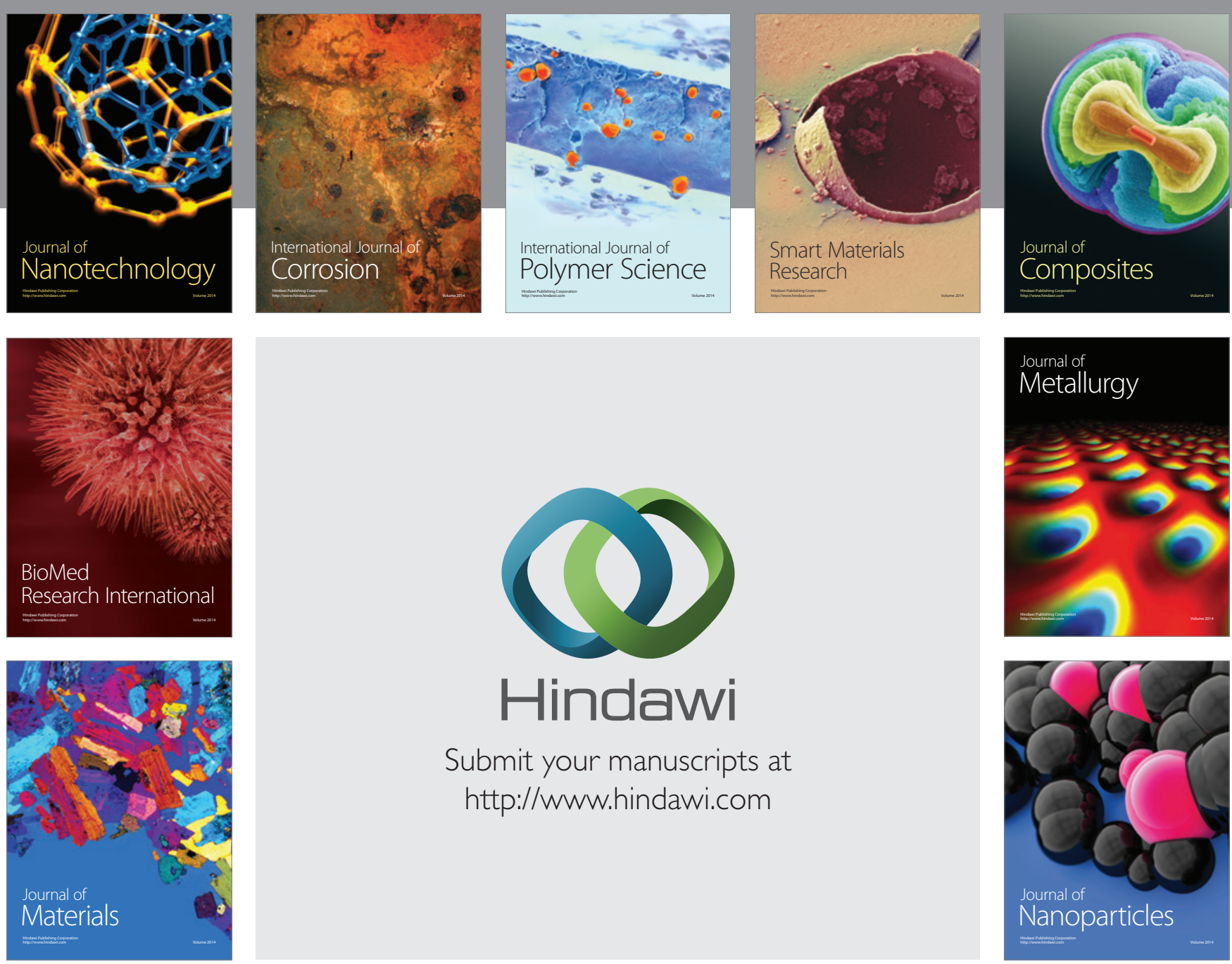

Submit your manuscripts at http://www.hindawi.com
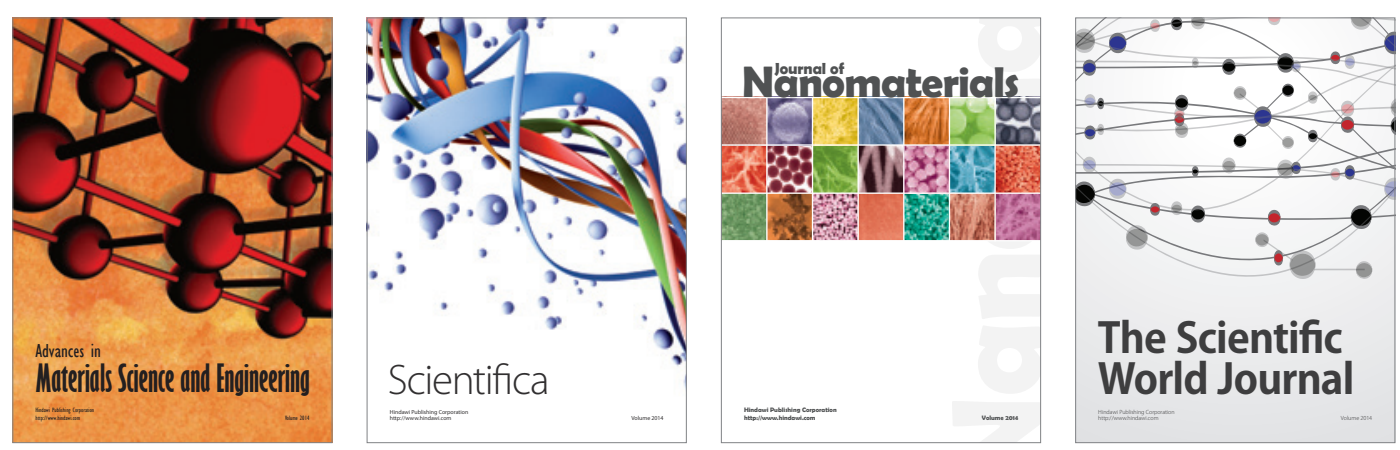

\section{The Scientific World Journal}
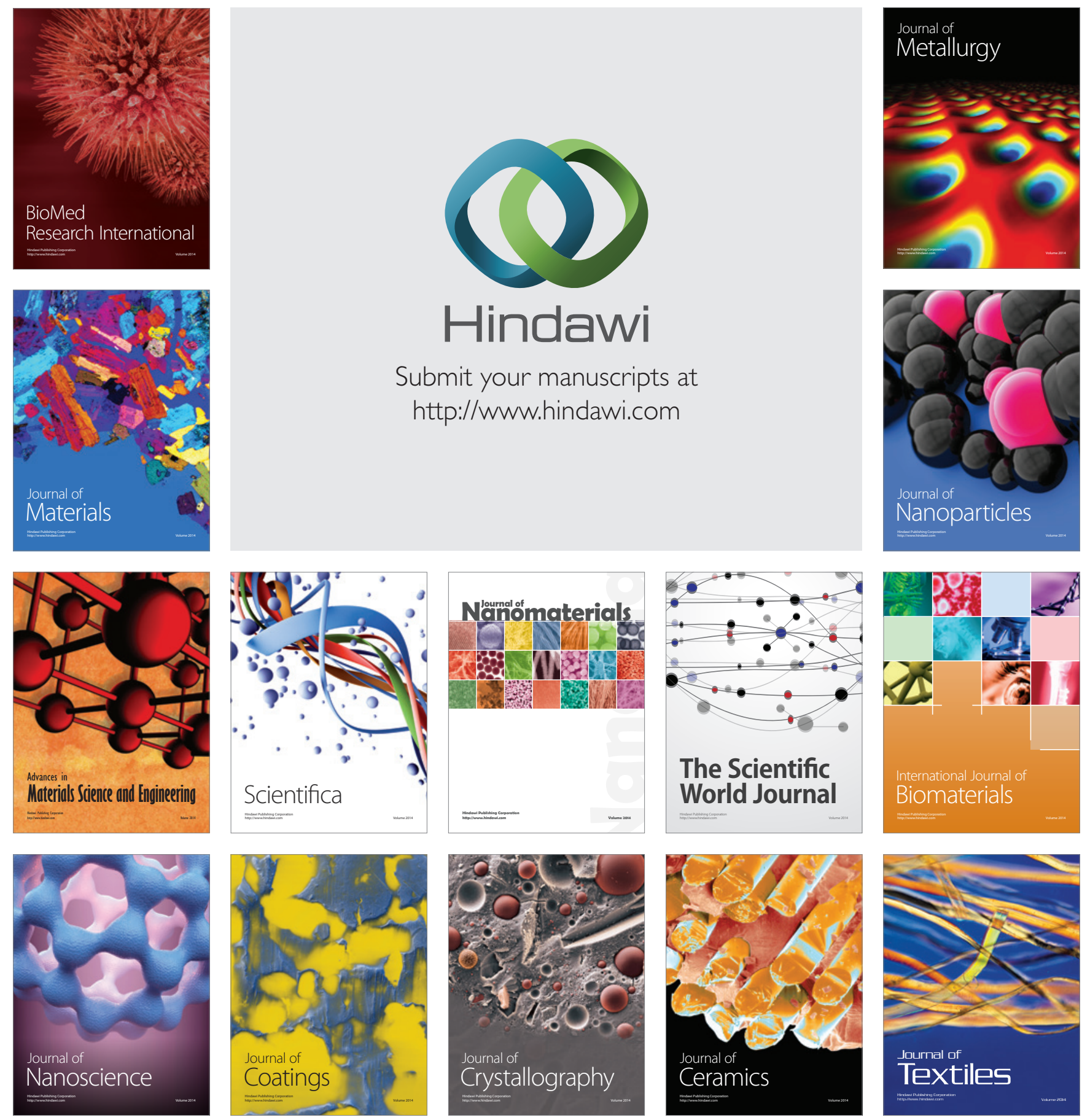